\title{
Land Suitability for Rice by Agro-Ecological Zone in Majene Regency, West Sulawesi, Indonesia
}

\author{
Syamsuddin \& Marthen P. Sirappa (Corresponding author) \\ Reseachers at Indonesian Agency for Agricultural Research and Development, \\ Assessment Institute for Agricultural Technology of West Sulawesi, Indonesia. \\ E-mail: mpsirappa@gmail.com
}

Received: October 23, 2017

Accepted: November 10, 2017

doi:10.5296/jas.v6i1.12408

URL: https://doi.org/10.5296/jas.v6i1.12408

\begin{abstract}
In order to support the self-sufficiency of food, especially rice, the government made special efforts to increase rice production in several ways, such as increased production, improved cropping index, and the expansion of planting area. In relation to the increase in crop production, data and information of land resource is necessary for optimal land use, focused and efficient through the surveying and mapping of land resources. Land surveying and mapping activities carried out in Majene Regency on a scale of 1: 50,000. Its objective was to determine the land suitability for food crops, especially lowland rice and upland rice in Majene Regency, West Sulawesi to support self-sufficiency in rice. Land evaluation results indicate that the suitability of land for rice crops of the total land area of 91,322 ha survey are as follows: (a) land that is quite appropriate (S2) for lowland rice area of 6,259 ha $(6.85 \%)$ consists of two subclasses, namely S2wa an area of 5,552 ha $(6.08 \%)$ by a factor limiting the availability of water (moderate rainfall), and S2wa, eh area of 707 ha $(0.77 \%)$ by a factor limiting the availability of water and slopes of 3-8\%; (b) land that is quite appropriate (S2) for upland rice area of 4,957 ha (5.42\%), consists of two subclasses, namely S2na an area of 4,250 ha $(4.65 \%)$ by a factor limiting the availability of nutrients low-medium, and S2na, eh area of 707 ha $(0.77 \%)$ with the limiting factor being the availability of nutrients and low-slope 3-8\%; while land classified in accordance marginal (S3) for upland rice area of 1,816 ha (1.99\%), consists of two subclasses, namely S3rc an area of 1,302 ha (1.43\%) with limiting factors impeded drainage, and S3eh an area of 514 ha $(0.56 \%)$ with limiting factor willayah wavy shape/slope of $8-15 \%$; and (c) land that is classified as not suitable (N) area of $84,227-84,741$ ha or approximately 92.23 to $92.79 \%$ with a limiting factor slopes $>15 \%$, very shallow soil, drainage severely hampered, and the danger of sulfidic materials.
\end{abstract}

Keywords: Land suitability, rice plants, the limiting factor, Agro-Ecological Zones. 


\section{Introduction}

The need for foodstuffs increases as the population increases, so it needs to be balanced with the provision of sufficient agricultural land resources in order to be sustainable national food availability. Data and information on land resources are clear, accurate and reliable is one important factor in optimizing land use in a sustainable manner, as well as a significant contributing factor in achieving the target of increasing food production, especially rice. The target achievement for rice production in 2015 amount to 73.40 million tonnes of rice with a growth of $2.21 \%$. The failure of agricultural development that occurs, often due to the inaccuracy of the data and information of the land resources.

Preparation of Agro-Ecological Zone map 1: 250,000 scale is one of the data collection activities and land resource information that has been done. The preparation of this map has been implemented by the Ministry of Agriculture in Indonesia through a network research and assessment since 1996. The map is very useful as a basic reference on the level of regional or national planning, while for utilization on a scale of operations should be followed by a larger scale is $1: 50,000$. On a scale of detail the conformity assessment of land used as a basis for preparing the zoning map commodities in various agro-ecological zones.

The agricultural sector is still the mainstay of livelihoods in West Sulawesi. West Sulawesi is one area that is being intensified development of the agricultural sector. Revenues Gross Regional Domestic Product (GRDP) of West Sulawesi Province for the agricultural sector by 49\%. Some major food commodities at provincial and district levels, among others, rice, cassava, corn, and soybeans (West Sulawesi CBS, 2013). Rice became an important commodity in West Sulawesi because the number of farmers engaged in cultivation of these commodities is quite a lot, in addition to its contribution to the GDP district and provincial high enough.

Program development for increased productivity of rice, corn and soybeans and other food commodities in West Sulawesi continues to be done by the provincial and district governments. The program is done either by increasing the land area (extension) on the commodity. Potential land for development food commodities is still quite extensive. But the use of land for food crops in addition to considering the terms of land use, technical and socio-cultural factors of local communities is also a consideration. Commodities requires optimal conditions and specific land to be able to produce optimally. Suitability of land with plants that will optimize the growth of the plant can produce optimally.

In order to support the planning of the development of food crops, the main requirements that must be met is the availability of data agro-climatic resources, water and soil that covers spatial data agro-climatic resources, water and soil on a scale of 1: 250,000. For the development of more operational planning at the district level, the data and information necessary land resources on a scale of 1: 50,000. Data and information on land resources 1: 50,000 scale is very useful to determine potential areas that can be developed for the cultivation of competitive commodities, drafting zoning leading commodity management and gathering of alternative technologies that can be applied in any part agroekosistem appropriate development of land capability. 
Analysis approach terrain is used to integrate the technique satellite image interpretation, contour maps, and field verification to obtain information resources agro-climate, water and soil of an area more easily and quickly (Van Zuidam, 1986; Mitchell and Howard, 1978; Kips et al., 1981; Dent et al., 1977; Desaunettes in Dent et al., 1977).

To formulate plans and strategies for the development of food crops in agricultural commodities should be supported by the data and comprehensive information on land resources, potential, production and productivity of crops as well as human resources support, social, economic, institutional and other components associated with the development aspects of agriculture. Data and information obtained through the survey resource potential climate, water and soil.

This study aims to provide an overview of land suitability of Majene Regency, West Sulawesi, Indonesia to crops of lowland rice and upland rice and zoning maps at scales of 1: 50,000.

\section{Methodology}

\subsection{Place and Time}

Survey to determine the potential and suitability of land and preparation of zoning maps commodity food crops in West Sulawesi in 2013 carried out in Majene Regency on a scale of 1: 50,000. Implementation of the activities took place from January to December 2013.

\subsection{Materials and Equipment}

Materials and equipment for the purposes of field activities are satellite images Landsat Thematic Mapper (TM), Basic Map (RBI Map digital, scale 1: 50.000), Thematic Maps (Map Land Review the scale of 1: 250,000 digital of Majene Regency), Map Usage Land, Map Geology, Dems who already have the same projection with RBI Maps, map the status of forests, data/map climate, socio-economic data and commodities in the regions.

In the process of implementing the activities AEZ at this location, required some equipment (a set of computers and equipment field), with the following specifications:

(a) Computer (minimum specification) are:

- Hardware: Intel Pentium PC, 64 MB RAM, HD 2 GB or larger. - The Deskjet Printer A3 size color - Software : Operating System Windows 2007, Microsoft Office, ArcView, ArcGIS, and others.

\section{(b) Field Equipment}

Equipment for ground observations in the field, consisting of: mineral soil drill, knife airy, Muncell Soil Color Charts, pH truogh, compass, Abney level, altimeter, and a loupe. In addition to the above-mentioned equipment, also required "a form" to record observations in the field land and filling instructions. Keduannya (a form and instructions for filling) refers to the Center for Agricultural Land Resources, the Agency for Agricultural Research in Bogor. 


\subsection{Methods of Implementation}

AEZ map preparation for the development of agricultural commodity crops, especially lowland rice and upland rice scale of 1: 50,000 in Majene district, carried out through several stages: an inventory of land resources, socio-economic and land resources evaluation. All data is processed in a data base format both tabular and spatial schemes of work in the preparation of a map scale of 1: 50,000 in Majene. Other phases are: preparation of land units map interpretation, field verification, finalization of map unit of land, land evaluation and preparation of AEZ maps, and preparation of reports. Flow diagram of the preparation of agricultural commodities based AEZ zoning map scale of 1: 50,000 is presented in Figure 1.

Preparation of agricultural commodities based AEZ zoning map scale of 1: 50,000 consists of several phases of activity, namely:

a Preparation of a map of land units. This activity begins with preparing the RBI digital map scale of 1: 50,000 as the base map. Map of land units 1: 50,000 scale are developed based on soil maps review the scale of 1: 250,000 (as background) by way deriving elements of land units, namely: landform, lithology, relief, and elevation, with the help of geological maps and the DEMs are already have the same projection to RBI maps. In the module will describe how deriving lithology, relief and slopes, as well as some training, in order to obtain a map of land units are ready for use as a field map.

b Verify, morphological observation of soil and soil sampling in the field. Field activities aimed at: (a) validation/verification of the results of the interpretation of land units and observing soil/land, (b) validation of the results of the interpretation of land use (c) soil sampling, (d) the collection of climate data, (e) the collection of social data economic, and (f) other secondary data collection, and the improvement of land units map the field. Soil morphological observation made on soil profiles include texture, color, structure, consistency, rooting circumstances, measurement of $\mathrm{pH}$, and others. Soil sampling for the purposes of soil classification is done at each layer based horizonisation, whereas for the purposes of the evaluation of the land was taken at a depth of $0-30 \mathrm{~cm}$ and $30-60 \mathrm{~cm}$ by the composite.

c Preparation of land use maps. This activity begins with interpretation of satellite images TM is on screen in the computer, to sort out the land use based classification.

d Land evaluation is the process of the performance assessment the land if it is used for a specific use (FAO, 1976). Land evaluation can be done by matching the quality/characteristics of the land (Land Quality/Land Characteritic, LQ/LC) with the requirements of land use (Land Use Requirement, LUR) is desired by the use of certain land (Land Utilization Types, LUT). Land use requirements are the properties that need to be owned by the land so that land use types that can be applied in an optimal and sustainable production. Therefore, the requirements of land use not only contain the growing requirements of plants but also the requirements management, conservation requirements/environment (conservation/environment requirement). Land use requirements used in this study refers to the Technical Guidelines for the Evaluation of 
Land Agricultural Commodities Revised Edition (Center for Agricultural Land Resources 2011). Land quality is a complex trait that affects a class of land suitability of certain types of land use. Land quality is offered properties (supply) by land and land use requirements is the demand of land use types. Land quality can be determined in the field, but it is generally determined by the characteristics of the land. Characteristics of land is the land properties that can be measured or estimated, while the quality of the land may consist of one or more characteristics of the land. Thus, the characteristics of the land does not directly affect land suitability classes, but through its influence on the quality of land.

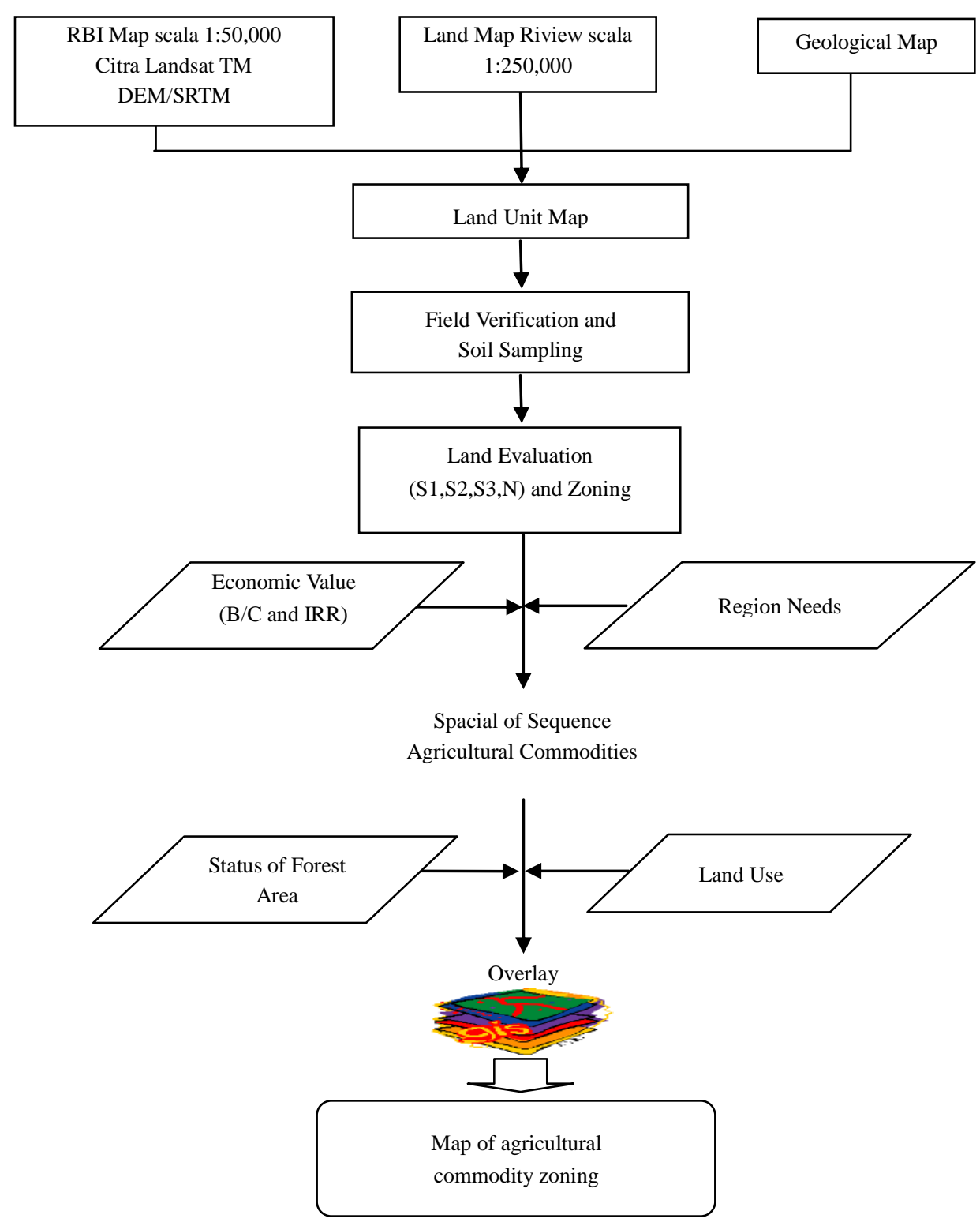

Figure 1. Flow diagram of the preparation of zoning maps of agricultural commodities 
Zoning of agricultural commodities, which take into consideration the results of the evaluation of land for some agricultural commodities, maps of current land use (existing landuse), the results of interpretation of Landsat imagery and field verification, map the status of forests, the economic value of the commodities which were evaluated comprised of parameters BCR (benefit cost ratio), RCR (revenue cost ratio), NVP (net present value), IRR (internal rate of return), input and revenue, and the priority of competitive commodities based on the desire/priorities identified by the local government. The principle of land suitability evaluation computerized using the access program 2010, which was given the name of Land Suitability Assessment System (LSAS) Version 1.0 has been developed in Center for Agricultural Land Resources.

\section{Results and Discussion}

\subsection{Characteristics of Region}

\subsubsection{Geographycal Conditions}

The Majene Regency with Banggae its capital is located between $2^{\circ} 38^{\prime} 45^{\prime \prime}-3^{\circ} 38^{\prime} 15^{\prime \prime}$ South Latitude and $118^{\circ} 45^{\prime} 00^{\prime \prime}-119^{\circ} 4^{\prime} 45^{\prime}$ East Longitude. This Regency was bounded by Mamuju Regency at the North and Polewali Mandar Regency at the East, Bound of South and West were Gulf of Mandar and Makassar Strait.

Majene as one of the districts of West Sulawesi province with the administrative center located in the town of Majene. The study area is the entire district Majene by administrative boundaries issued by CBS in 2013, covers an area of approximately of $947.84 \mathrm{~km}^{2}$, consists of 8 districts, namely Banggae, East Banggae, Pamboang, Sendana, Tamero'do Sendana, Tubo Sendana, Malunda and Ulumanda district.

\subsubsection{Agriculture Conditions}

In field crops, commodities that occupy the largest harvested area is upland rice, following wetland rice, cassava, maize, soybean and the lowest was, as in Table 1. The average productivity of food crops in the last 2 years (2012-2013) is fluctuating, as shown in Table 1.

Table 1. The area, production and productivity of rice plants in Majene district in 2012 and 2013

\begin{tabular}{lllllll}
\hline \multirow{2}{*}{ Commodities } & Year 2012 & \multicolumn{5}{c}{ Year 2013 } \\
\cline { 2 - 7 } & $\begin{array}{l}\text { Harvested } \\
\text { Area (ha) }\end{array}$ & $\begin{array}{l}\text { Production } \\
(\mathrm{t})\end{array}$ & $\begin{array}{l}\text { Productivity } \\
\left(\mathrm{t} \mathrm{ha}^{-1}\right)\end{array}$ & $\begin{array}{l}\text { Harvested } \\
\text { Area (ha) }\end{array}$ & $\begin{array}{l}\text { Production } \\
(\mathrm{t})\end{array}$ & $\begin{array}{l}\text { Productivity } \\
\left(\mathrm{t} \mathrm{ha}^{-1}\right)\end{array}$ \\
\hline Lowland Rice & 1,305 & 7,569 & 5.80 & 1,470 & 7,919 & 5.39 \\
Upland Rice & 1,400 & 5,740 & 4.10 & 1,966 & 7,968 & 4.05 \\
Corn & 572 & 2,424 & 4.24 & 394 & 2,493 & 6.33 \\
Cassava & 567 & 8,250 & 14.55 & 495 & 7,053 & 14.25 \\
Sweet & 160 & 1,280 & 8.00 & 125 & 1,001 & 8.01 \\
Potato & & & & & & 0.90 \\
Peanut & 119 & 110 & 0.92 & 80 & 12 & 0.99 \\
Green Beans & 182 & 190 & 1.04 & 160 & - & - \\
Soybean & 1 & 1 & 1.00 & - & - & 0.98 \\
\hline
\end{tabular}

Source : CBS of Majene Regency (2013) 


\section{$\Lambda$ Macrothink}

\subsubsection{Climate and Hydrology}

Climate and water resources is a major deciding factor in determining the level of land suitability, productivity, quality of agricultural products and the selection of appropriate technology with the characteristics of each region.

Based Map Resources Climate Indonesia (Research Institute for Agro-Climate and Hydrology, 2003) most of the research sites, especially the area around Majene included in arid climates with pattern II-B, which is the region that has rainfall from 1,000 to $2,000 \mathrm{~mm}$ per year with dry months $(<100 \mathrm{~mm}$ per month) $<4$ months and months of wet $(>200 \mathrm{~mm}$ per month) $<4$ months. Northern regions ranging from about Lombongan up to Malunda or border with Mamuju including in wet climates and including patterns of III-C, the region has a rainfall of 2,000 to $3,000 \mathrm{~mm}$ per year with dry months ( $<100 \mathrm{~mm} /$ month) $<4$ months and months of wet (> $200 \mathrm{~mm}$ per month) 6-8 months.

Based on the criteria Oldeman (1975), the Majene regency including Agroclimate into several zones, namely B1, C1, D1, D2 and D3. Regions in the north in general, including agro-climatic zone B1 with wet months (> $200 \mathrm{~mm}$ per month) in a row for 7-9 months and months of dry ( $<100 \mathrm{~mm}$ per month) consecutive $<2$ months, C1 with wet months $(>200$ $\mathrm{mm}$ per month) in a row for 5-6 months and months of dry ( $<100 \mathrm{~mm}$ per month) consecutive $<2$ months and D1 with wet months (> $200 \mathrm{~mm}$ per month) in a row for 3-4 months and the dry months $(<100 \mathrm{~mm}$ per month) consecutive $<2$ months. Lying areas around Malunda including D2 with wet months (> $200 \mathrm{~mm}$ per month) in a row for 3-4 months and months of dry ( $<100 \mathrm{~mm}$ per month) consecutive $<2$ months. Southern part of the region around the town of Majene including D3 with wet month rainfall (> $200 \mathrm{~mm}$ per month) in a row for 3-4 months and months of dry (<100 mm per month) consecutive 3-5 months (Figure 2 and 3).

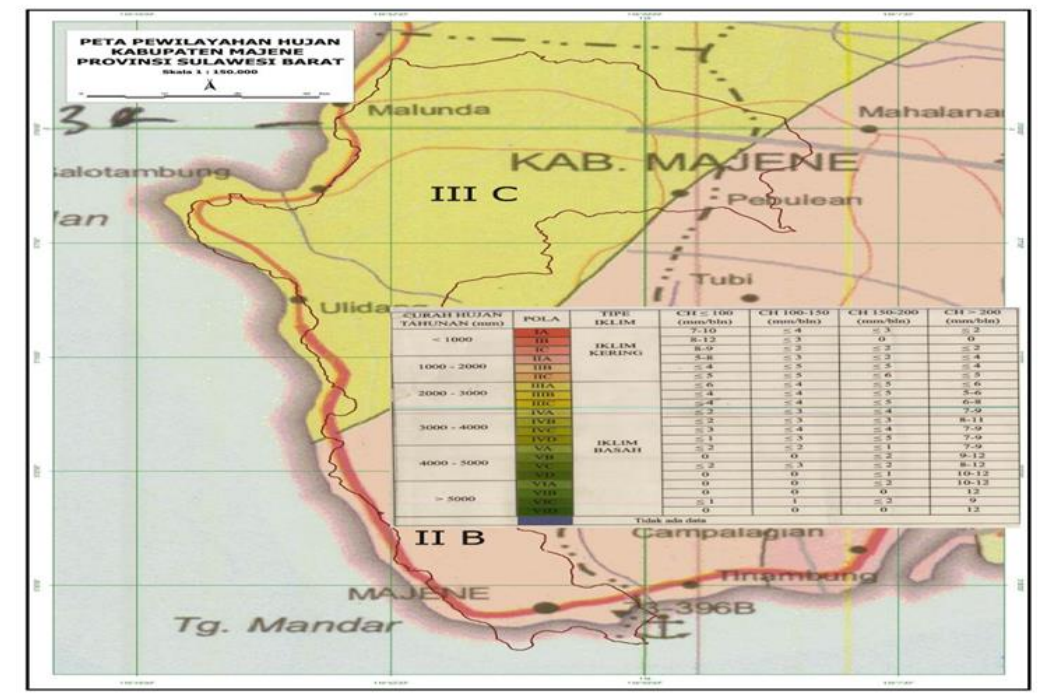

Figure 2. Map of the zone rainfall Majene Regency, West Sulawesi, Indonesia 


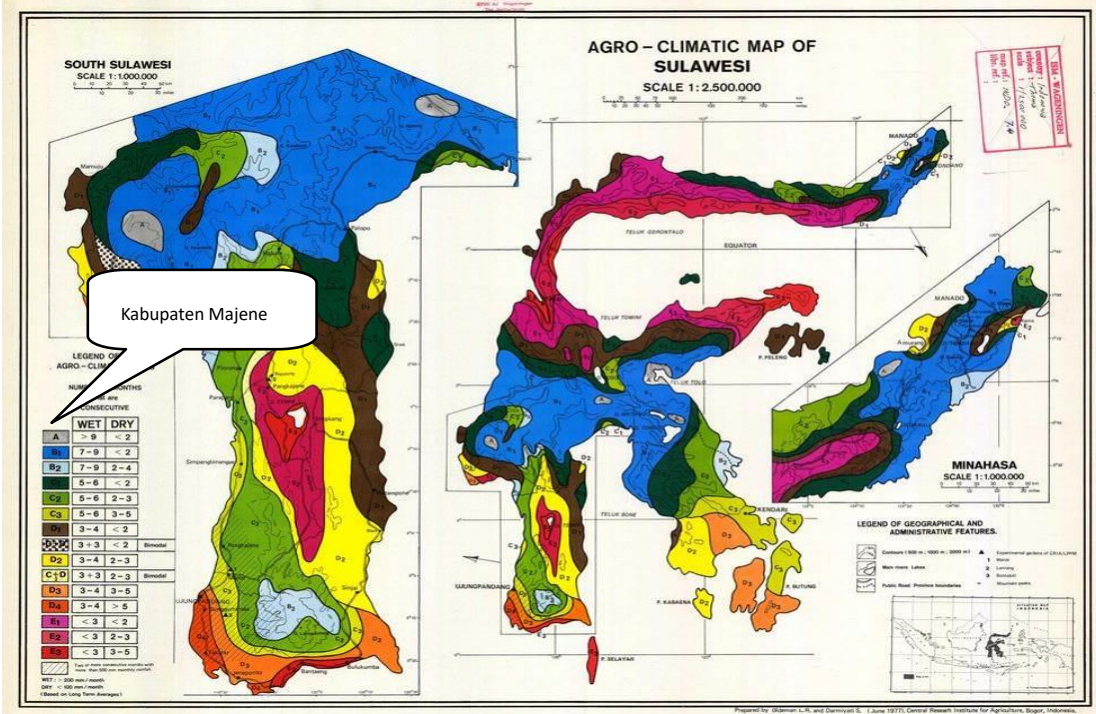

Figure 3. Map Zone Regional Research and surrounding Agroclimate

Monthly rainfall in Majene regency fluctuating within the last 5 years (2009 to 2013). Based on data in Table 2 and Figure 4, the peak rainfall occurs in December and January, while rainfall of moderate intensity occurred in February - May and in September-November. Variations in rainfall that occurred throughout the year in the Majene regency can be utilized in setting the cropping pattern, especially food crops. In the district there are some streams Majene important for agriculture, among others Malunda river, Tubo river, Lombongan river, Tamerodo river, Lembang Mosso river and Lembang Pamboang river. The rivers are still flowing throughout the year.

Table 2. Rainfall every month from 2009 to 2013 in Majene Regency, West Sulawesi, Indonesia

\begin{tabular}{llllllr}
\hline \multirow{2}{*}{ Month } & Year & \multicolumn{2}{l}{ 2013 } & \multicolumn{2}{c}{$\begin{array}{l}\text { Average } \\
(\mathrm{mm})\end{array}$} \\
\cline { 2 - 6 } & $\begin{array}{l}2009 \\
(\mathrm{~mm})\end{array}$ & $\begin{array}{l}2010 \\
(\mathrm{~mm})\end{array}$ & $\begin{array}{l}2011 \\
(\mathrm{~mm})\end{array}$ & $\begin{array}{l}2012 \\
(\mathrm{~mm})\end{array}$ & $\begin{array}{l}2013 \\
(\mathrm{~mm})\end{array}$ & 271.0 \\
\hline January & 597.8 & 218.5 & 197.8 & 74.5 & 266.4 & 186.6 \\
February & 163.2 & 292.3 & 168.7 & 129.3 & 179.7 & 105.6 \\
March & 139.6 & 84.9 & 118.1 & 97.8 & 87.6 & 130.9 \\
April & 148.0 & 115.1 & 208.4 & 45.5 & 137.4 & 151.2 \\
May & 122.3 & 196.1 & 88.6 & 224.9 & 124.3 & 72.3 \\
Juny & 20.6 & 160.2 & 37.2 & 94.3 & 49.2 & 94.2 \\
July & 59.5 & 170.4 & 1.6 & 64.6 & 175.1 & 72.2 \\
August & 32.6 & 206.4 & 4.7 & 13.5 & 104.0 & 92.6 \\
September & 6.2 & 303.1 & 26.0 & 10.1 & 117.4 & 116.8 \\
October & 116.5 & 215.9 & 152.5 & 43.4 & 55.6 & 233.7 \\
November & 152.5 & 224.9 & 199.8 & 80.6 & 206.0 & 179.5 \\
December & 154.1 & 169.3 & 456.4 & 209.3 & & \\
\hline
\end{tabular}

Source: CBS of Majene Regency (2013) 


\section{Macrothink}

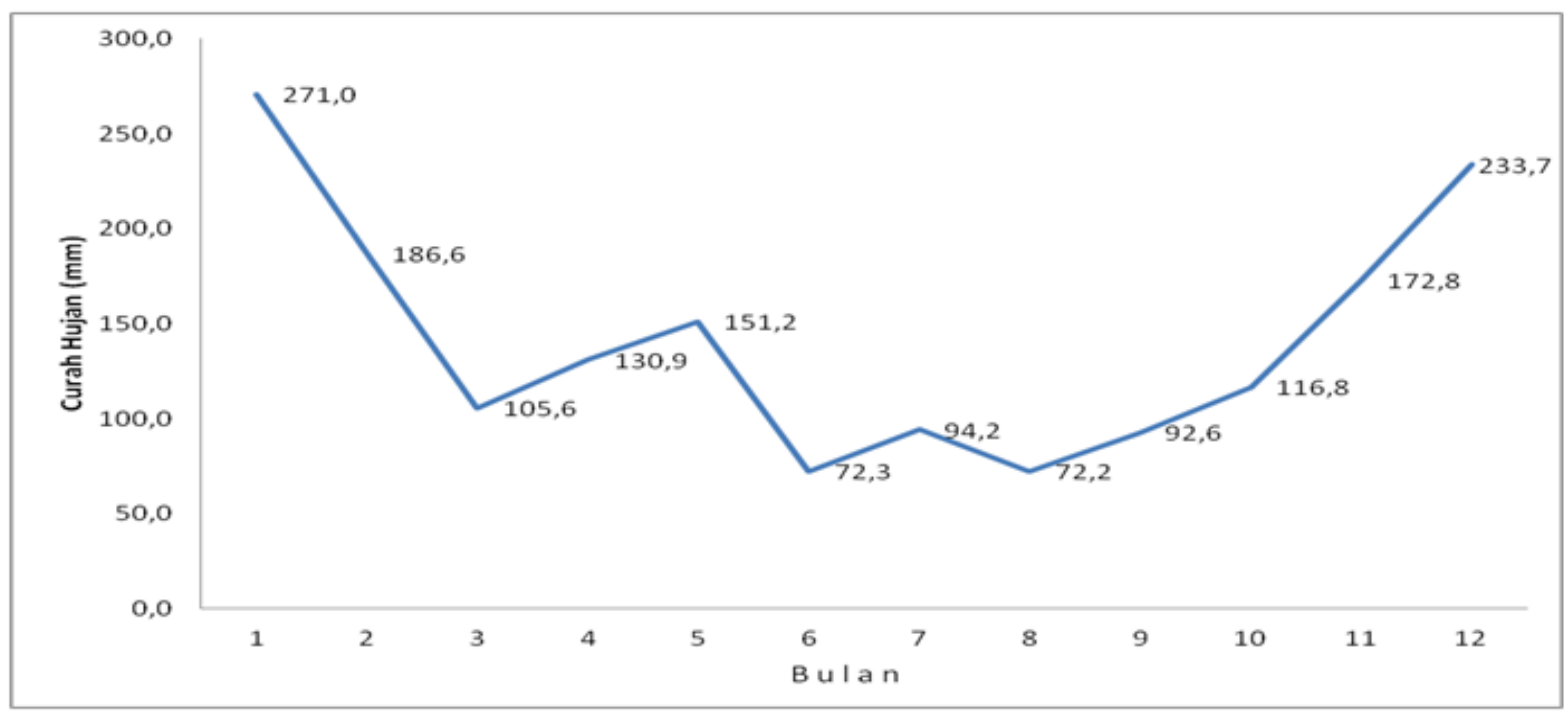

Figure 4. Variation of the average monthly rainfall in 2008-2012 Majene Regency

\subsubsection{Soil Types and Properties}

Based on the geological map and the identification in the field and supported by data from previous studies show that the type of soil found in the study site evolved from the parent material sandstone, calcareous sandstone, limestone, marl, rocks volkan andesite-basalt and materials deposition (alluvium and marin). From the results in the field of identification, the type of soil found in this area consists of 6 Order, 9 suborder, 11 subgroups and lowering the 16 subgroups soil classification according to Soil Taxonomy (Soil Survey Staff, 2010), as presented in Table 3.

Table 3. Soil Classification in Majene, West Sulawesi.

\begin{tabular}{llll}
\hline Ordo & Subordo & Grup & Subgrup \\
\hline Entisols & Aquents & Sulfaquents & Typic Sulfaquents \\
& Psamments & Udipsamments & Typic Udipsamments \\
& Orthents & Udorthents & Lithic Udorthents \\
Inceptisols & Aquepts & Endoaquepts & $\begin{array}{l}\text { Typic Endoaquepts } \\
\text { Fluvaquentic Endoaquepts }\end{array}$ \\
& & Vertic Endoaquepts \\
& Udepts & Dystrudepts & Aquic Dystrudepts \\
& & Typic Dystrudepts \\
& & Eutrudepts & Aquic Eutrudepts \\
& & Lithic Eutrudepts \\
Vertisols & Aquerts & Typic Eutrudepts \\
Molisols & Rendolls & Haprendolls & Typic Endoaquerts \\
Ultisols & Udults & Hapludults & Typic Hapludults \\
& & Paleudults & Typic Paleudults \\
Alfisols & Udalfs & Hapludalfs & Typic Hapludalfs \\
\hline
\end{tabular}


From 6 orders soil found, Inceptisols is a type of soil that is predominant in the district Majene, spread on a group landform tectonics, landform alluvial, and a small portion at the landform karst and landform volkan, made the parent of sandstone, silt and alluvium with relief flat to mountainous. Other types are also commonly found are Ultisols and Alfisols, especially in the group with the parent material volkan landform lava tuff, basaltic andesites and volcanic breccias.

Inceptisol is a type of soil that has developed characterized horizon kambik with base saturation $>60 \%$, in the soil solum $(75-100 \mathrm{~cm})$, topsoil grayed brown to brown (10 YR 4/3-5/3), topsoil Under $(50-100 \mathrm{~cm}$ ) light brownish gray $(10 \mathrm{YR} 6 / 2)$, the texture of the soil top layer and bottom layer of clay dusty clay - clay dusty, slightly acidic soil reaction ( $\mathrm{pH} 5.5$ to 6.5) with drainage conditions rather obstructed to moderate.

\subsection{Land Suitability Evaluation}

Data and information on soil, climate and other environmental physical properties as well as the requirements of growing plants, especially plants that have high economic value is very important in the optimal utilization of land resources, targeted and efficient. Therefore, soil data, climate and the physical properties of the environment that influence plant growth and aspects of management need to be identified and characterized through the survey and mapping of land resources, and subsequently interpreted for the purposes of particular use through land evaluation (Ritung et al., 2011),

Land evaluation is the performance assessment process the land if it is used for a specific use (FAO, 1976). Land evaluation can be done by matching the quality/characteristics of the land (Land Qualities/Land Characteritics, LQ/LC) with the requirements of land use (Land Use Requirement/ LUR) is desired by the use of certain land (Land Utilization Types/LUT).

Land use requirements are the properties that need to be owned by the land so that land use types that can be applied in an optimal and sustainable production. Therefore, the requirements of land use not only contain the growing requirements of plants but also the management requirements (requirements management), conservation requirements / environment (conservation / environment requirement). Land use requirements used in this training refers to the Technical Guidelines for the Evaluation of Land Agricultural Commodities Revised Edition (BBSDLP, 2011).

Land quality is a complex trait that affects a class of land suitability of certain types of land use. Land quality is offered properties (supply) by land and land use requirements is the demand of land use types. Land quality can be determined in the field, but it is generally determined by the characteristics of the land.

Characteristics of land is the land properties that can be measured or estimated. There is a very close relationship between the characteristics of the land with the land quality. Quality of land may consist of one or more characteristics of the land, thus land characteristics not directly affect land suitability classes, but its influence through the quality of the land. 
Table 4. Results of the assessment soil chemical properties (Status of N, P, K, soil pH, cation exchange capacity and base saturation) in Majene Regency, West Sulawesi

\begin{tabular}{llllllll}
\hline \multirow{2}{*}{ No. } & $\begin{array}{l}\text { Soil Classification } \\
\text { (USDA 2010) }\end{array}$ & \multicolumn{2}{l}{ Nutrient Status of N,, $\mathrm{K}$} \\
\cline { 3 - 8 } & $\mathrm{N}$ & $\mathrm{P}$ & $\mathrm{K}$ & $\mathrm{pH} \mathrm{H} \mathrm{H}_{2} \mathrm{O}$ & $\mathrm{CEC}$ & $\mathrm{BS}$ \\
\hline 1. & Lithic Udorthents & $\mathrm{L}$ & $\mathrm{VH}$ & $\mathrm{VH}$ & $\mathrm{AM}$ & $\mathrm{M}$ & $\mathrm{VH}$ \\
2. & Vertic Endoaquepts & $\mathrm{L}$ & $\mathrm{VH}$ & $\mathrm{VH}$ & $\mathrm{AM}$ & $\mathrm{L}$ & $\mathrm{VH}$ \\
3. & Typic Endoaquepts & $\mathrm{L}$ & $\mathrm{M}$ & $\mathrm{H}$ & $\mathrm{AM}$ & $\mathrm{H}$ & $\mathrm{VH}$ \\
4. & Lithic Eutrudepts & $(\mathrm{VL})$ & $\mathrm{VH}$ & $\mathrm{VH}$ & $(\mathrm{AM})$ & $(\mathrm{L}-\mathrm{VH})$ & $\mathrm{VH}$ \\
5. & Typic Eutrudepts & $\mathrm{VL}$ & $\mathrm{VH}$ & $\mathrm{VH}$ & $(\mathrm{AM})$ & $(\mathrm{L}-\mathrm{H})$ & $\mathrm{VH}$ \\
6. & Lithic Haprendolls & $\mathrm{M}$ & $\mathrm{VH}$ & $\mathrm{VH}$ & $\mathrm{N}$ & $\mathrm{H}$ & $\mathrm{VH}$ \\
7. & Typic Hapludalfs & $\mathrm{L}$ & $\mathrm{VH}$ & $\mathrm{H}$ & $\mathrm{AA}$ & $\mathrm{L}-\mathrm{M}$ & $\mathrm{VH}$ \\
8 & Typic Paleudults & $\mathrm{M} / \mathrm{L}$ & $\mathrm{M}$ & $\mathrm{H} / \mathrm{L}$ & $\mathrm{M}$ & $\mathrm{L}$ & $\mathrm{L}-\mathrm{VL}$ \\
\hline
\end{tabular}

Remark : L = Low; $\mathrm{M}=$ Medium; $\mathrm{H}=$ High; $\mathrm{VL}=$ Very Low; VH = Very High

$\mathrm{CEC}=$ Cation Excange Capacity; $\mathrm{BS}=$ Base Saturity

Results of soil analysis is done based on the classification of the land has made assessment of chemical properties of soil, as presented in Table 4. Nitrogen soil is generally considered to be very low to low, generally slightly acidic soil $\mathrm{pH}$, whereas $\mathrm{P}, \mathrm{K}$ and $\mathrm{BS}$ soil is generally considered very high.

Results of the evaluation of the suitability of land for lowland rice and upland rice in Majene presented in Tables 5 and 6. Land that is quite appropriate (S2) for paddy rice area of 6,259 ha $(6.85 \%)$ of the total area of the survey, consisting of 2 subclass, namely S2wa an area of 5,552 ha $(6.08 \%)$ by a factor limiting the availability of water (moderate rainfall), and S2wa, eh area of 707 ha $(0.77 \%)$ by limiting the availability of water and slopes of 3-8\%. While the remaining area of 84,741 ha or $92.79 \%$ of the total area of the survey pertained not suitable (N) by a factor limiting the slopes of $>15 \%$, very shallow soil and the danger of sulfidic materials. The suitability of land for paddy rice in Majene presented in Table 6. Class of land suitability is quite appropriate (S2) by a factor limiting the availability of water (wa) and slope choppy (er) can be upgraded to the appropriate class (S1) if the factors limiting the availability of water can be overcome with the manufacture of irrigation and wavy slopes with a terrace pembauatn tering, though necessary inputs are classified as moderate to high.

Table 5. Suitability of land for paddy rice in Majene, West Sulawesi, 2013

\begin{tabular}{llll}
\hline \multirow{2}{*}{ Land Suitability } & Limiting factor & wide & \\
\cline { 3 - 4 } & & Ha & $\%$ \\
\hline S2wa & Water availability & 5,552 & 6.08 \\
S2wa,eh & Availability of water and slopes/relief choopy & 707 & 0.77 \\
Neh & Slope $>15 \%$ & 84,530 & 92.56 \\
Nrc,xs & Drainage severely hampered and sulfidic materials & 211 & 0.23 \\
Td & Village/town & 322 & 0.35 \\
\hline Amount & & 91,322 & 100.00 \\
\hline
\end{tabular}


Land that is quite appropriate (S2) for upland rice area of 4,957 ha (5.42\%) consists of two subclasses, namely S2na an area of 4,250 ha (4.65\%) by a limiting factor is the availability of nutrients low-medium, and S2na, eh area 707 ha $(0.77 \%)$ with limiting factor is the availability of low-nutrient medium and slopes of 3-8\%. Classified in accordance marginal land (S3) consists of S3rc an area of 1,302 ha (1.43\%) with a barrier drainage is blocked, and S3eh an area of 514 ha $(0.56 \%)$ with a barrier willayah wavy shape/slope of $8-15 \%$. While the remaining area of 84,227 ha or $92.23 \%$ classified as not suitable $(\mathrm{N})$ by a limiting factor is the slopes of $>15 \%$, very shallow soil, drainage severely hampered and the danger of sulfidic materials. Suitability of land for upland rice in Majene Regency are presented in Table 6.

Table 6. Suitability of land for upland rice in Majene Regency, West Sulawesi, 2013

\begin{tabular}{|c|c|c|c|}
\hline \multirow{2}{*}{ Land Suitability } & \multirow{2}{*}{ Limiting factor } & \multicolumn{2}{|l|}{ Wide } \\
\hline & & $\mathrm{Ha}$ & $\%$ \\
\hline S2na & Nutrient availability medium & 4,250 & 4.65 \\
\hline S2na,eh & $\begin{array}{l}\text { Nutrient availability medium and slope } \\
3-8 \%\end{array}$ & 707 & 0.77 \\
\hline S3rc & Hampered drainage & 1,302 & 1.43 \\
\hline S3eh & Bumpy slope & 514 & 0.56 \\
\hline Neh & Slope $>15 \%$ & 84,016 & 92.00 \\
\hline $\mathrm{Nrc}, \mathrm{xs}$ & $\begin{array}{l}\text { Severely hampered drainage and sulfidic } \\
\text { materials }\end{array}$ & 211 & 0.23 \\
\hline \multirow[t]{2}{*}{$\mathrm{Td}$} & Village/town and the body of water & 322 & 0.35 \\
\hline & & & 100.00 \\
\hline Amount & & 91,322 & \\
\hline
\end{tabular}

Class suitability of land for upland rice which is quite appropriate (S2) by a limiting factor is the availability of nutrients being (na) and slope choppy (er) can be increased to a class suit (S1) with input fertilizer and terrace with a low input to high. While the land suitability classes were classified as marginally suitable (S3) with limiting factors is hampered drainage (rc) and bumpy slope (eh) can be increased to sufficiently appropriate class (S2) with moderate to high input is organic matter and terrace.

Repairs to the limiting factor slope $>15 \%$ generally can not be done because its use is included for plantations, while the material for sulfidic can be repaired with the arrangement of the groundwater, where the ground water level should be above the material layer sulfidic although it requires a level of management medium-high so economically inefficient. On the lands that have shallow solum with herbaceous vegetation advised planted with woody plants or forestry crops of high economic value by making the planting hole as deep as $60-75 \mathrm{~cm}$ so that plant roots are not hampered and grow normally.

\subsection{Based Agricultural Commodities Zoning AEZ}

Data/information available land resources in the province of West Sulawesi is Agro-Ecological Zones map scale 1: 250,000. The map is a derivative of data/information 
that describes land resources grouping of a region into zones of agriculture development, farming and forestry systems and alternative commodity based on common biophysical characteristics (soil and climate) environment. Such information can be used as a basis for planning the development of regional agriculture, in order to keep the continuity of production and productivity as well as environmental sustainability. According to Amien et al. (1994), grouping the area into Agro-Ecological Zones, can assist in assembly and application of technology packages that are tailored to the specific physical environmental conditions.

Operational planning for agricultural development required a more detailed scale in the preparation of zoning agricultural commodities on a scale of 1: 50,000. On the scale required more detailed information especially with regard to the nature and characteristics of the land, as a major prerequisite in the evaluation of land. The nature and characteristics of the land used in the evaluation of the land is the land (rooting media, nutrient retention, toxicity), climate (temperature, elevation, rainfall), terrain (slopes and rock outcrops), the danger of flooding and erosion hazards (CSR/FAO, 1983; Djaenudin et al., 2000).

Zoning of agricultural commodities is an activity that generates the direction of land use by considering the carrying capacity of the land (land suitability), current land use (existing landuse), socio-economic conditions (competitive and comparative), table of priority agricultural crops in the regions, and the map of the status of forest areas. Results drafting zoning agricultural commodities of Majene Regency served as farm agroecological zone maps in the scale of 1: 50,000 with the zoning details as in Table 7.

Table 7. Map zoning agricultural commodities of Mejene Regency based on AEZ

\begin{tabular}{|c|c|c|c|}
\hline \multirow{2}{*}{ Zone } & \multirow{2}{*}{$\begin{array}{l}\text { Farming system/Alternative Agricultural } \\
\text { Commodities }\end{array}$} & \multicolumn{2}{|l|}{ Wide } \\
\hline & & $\mathrm{Ha}$ & $\%$ \\
\hline \multicolumn{4}{|c|}{ Wetland Agriculture: } \\
\hline $\mathrm{IV} / \mathrm{Wr}$ & Lowland rice, corm, soybean, vegetable, onion & 1,302 & 1.43 \\
\hline \multicolumn{4}{|c|}{ Dryland Agriculture, food crops: } \\
\hline IV/Dfsp & Upland rice, corn, soybean, & 4,958 & 5.43 \\
\hline \multicolumn{4}{|c|}{ Dryland Agriculture, annual crop/plantation, food crop: } \\
\hline III/Dei/Dfsp & $\begin{array}{l}\text { cacao, robusta coffee, coconut, upland rice, } \\
\text { corn, soybean }\end{array}$ & 514 & 0.56 \\
\hline \multicolumn{4}{|c|}{ Dryland Agriculture, annual crop/plantation: } \\
\hline II/Dei & cacao, robusta coffee, coconut, cashew & 8,628 & 9.45 \\
\hline \multicolumn{4}{|c|}{ Freshwater fisheries and brackish: } \\
\hline IV/Wi & milkfish, shrimp & 211 & 0.23 \\
\hline \multicolumn{4}{|c|}{ Dryland forest: } \\
\hline $\mathrm{I} / \mathrm{Dj}$ & Dryland forest & 75,388 & 82.55 \\
\hline \multicolumn{4}{|l|}{ Others: } \\
\hline \multirow[t]{2}{*}{$\mathrm{Td}$} & Town/settlements & 322 & 0.35 \\
\hline & Amount & $\mathbf{9 1 , 3 2 3}$ & 100.00 \\
\hline
\end{tabular}




\section{$\Lambda$ Macrothink}

Results zoning commodities of Majene Regency be divided into 7 zones territory, which is 4 zone for agriculture (wetlands, dry land for food crops, dry land for annual crops/plantation and food, and the dry land to annual crops/plantation), one fisheries zone, one conservation zone, and one other zone (Figure 5). The fourth zone for agriculture, namely: agriculture wetlands zone (1,302 ha); zone of dry land agriculture crops (4,958 ha); dryland farming zone for annual crops/plantation and crops (514 ha); and dry land farming zone for annual crops/plantation (8,628 ha).

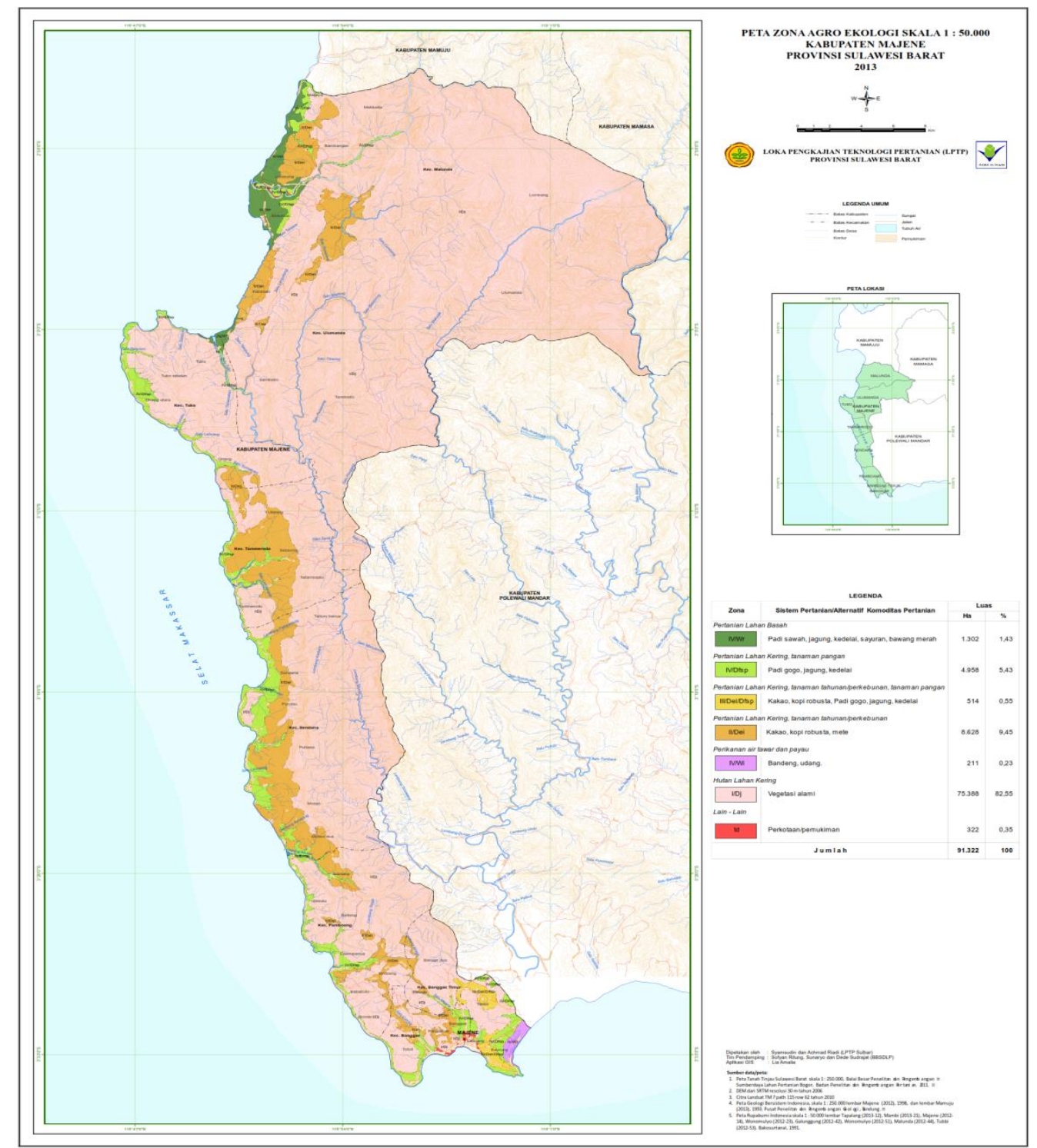

Figure 5. Agro-Ecological Zone Map scale 1: 50,000 Majene Regency

Based on the results of zoning, the area which includes crop farming zone covering an area of 6,774 ha or $7.42 \%$ of the total area of survey in Majene Regency. Of the area, approximately 1,302 ha $(1.43 \%)$ that is suitable for food crops wetlands (lowland rice, corn, soybeans, vegetables and onion), 4,958 ha $(5.43 \%)$ which is suitable for dryland farming crops (upland rice, corn, soybeans) and 514 ha $(0.56 \%)$ which is suitable for dryland farming of annual 
crops/plantation and food crops (cocoa, robusta coffee, coconut, upland rice, corn, soybeans). Proper management is needed, so that the use of land for plantation crops can be optimized and sustainable.

The low potential for agricultural land in the Majene Regency primarily due to this region has most of the areas that form the topography slopes $>40 \%$, as well as shallow to very shallow and rocky. Other zones for freshwater and brackish ponds, forests and others very wide, which is about of $83.14 \%$ (75,921 ha).

According to Suparto and Hartomi (2002), the zoning of agricultural commodities prepared taking into account the quality and availability of land resources, human resources, and infrastructure, in order to obtain optimal agricultural products and environmentally sound approach and agribusiness systems. Development of appropriate agricultural commodities in biophysical and economically beneficial, very important in the planning of technology assessment for development of superior commodities taking into account the ability of natural resources, human resources, and institutional so that sustainable development of the commodity (Sudaryanto and Syafa'at, 1999).

Van Zuidam (1986) argued that in the preparation of commodity zoning map scale of 1: 50.000 done through terrain analysis approach taking into account the characteristics of the land, namely relief, slope, geomorphology process, lithology/parent material, and hydrology as a parameter. Approach to terrain analysis methods have been carried out among others by Mitchell and Howard (1978), Kips et al. (1981), Dent et al. (1977), and Desaunettes in Dent et al. (1977).

Elements such as slope and level terrain incision has close links with the land suitability level, so that the delineation produced can be used as a basic unit in the land evaluation. In the hierarchy, the terrain can be distinguished based on the scale of the map (1: 250,000 - 1: $10,000)$ into four categories, namely: province terrain, terrain system, terrain units and terrain component. Category terrain units equivalent to land catena used to delineate land units on a scale of 1: 50,000 (Kips et al., 1981; van Zuidam, 1986; Meijerink, 1988).

\section{Conclusions}

Based on the results of the study and discussion can be concluded: (1) the use of land in Majene Regency is dominated by forest, shrub and grassland/shrub with hilly to mountainous territory form the predominant slope of more than $25 \%$, solum shallow to very shallow and rocky with elevation ranging from 0 to $1,500 \mathrm{~m}$ above sea level, while land for agriculture is very narrow form of mixed farms and rice paddies, (2) based on the evaluation of land, mostly classified as not suitable $(\mathrm{N})$ to the farm, which is about of $83.14 \%(75,921$ ha) with limiting factor slopes $>40 \%$, the soil is very shallow-shallow and rocky and sulfidic layers. Land that is quite appropriate (S2) and the appropriate marginal (S3) for crops only about of 6,774 ha or $7.42 \%$ of the total area of the survey, with a low level to high management to improve compliance grade, (3) referral land use taking into account the current land use (existing landuse), socio-economic conditions (competitive and comparative), seed crops priority table area, and a map of the status of the forest area, the Majene Regency distinguished on 7 
zoning consists of four zones for agriculture, one fishery zone, one conservation zone, and others zone. Zone agriculture for food crops covering an area of 6,774 ha or $7.42 \%$ of the total area of the survey, and (4) on a very shallow-shallow soil with herbaceous vegetation advised planted with woody plants or forestry crops of high economic value by making the planting hole as deep as $60-75 \mathrm{~cm}$ so that plant roots are not hampered and grow normally.

\section{References}

Amien, I., Sosiawan, H, \& Susanti, E. (1994). Agroekologi dan alternatif pengembangan pertanian di Sulawesi, Nusa Tenggara, dan Maluku. Prosiding Temu Konsultasi Sumberdaya Lahan untuk Pengembangan Kawasan Timur Indonesia. Palu, 17-20 Februari 1994. Hal. 239-260.

Balai Penelitian Agroklimat dan Hidrologi. (2003). Peta Sumberdaya Iklim Indonesia. Balai Penelitian Agroklimat dan Hidrologi, Badan Penelitian dan Pengembangan Pertanian.

BBSDLP. (2011). Petunjuk Teknis Evaluasi Lahan untuk Komoditas Pertanian. Edisi kedua tahun 2011. Balai Besar Penelitian dan Pengembangan Sumberdaya Lahan Pertanian, Badan Litbang Pertanian.

BPS Kabupaten Majene. (2013). Majene Dalam Angka 2013. Badan Pusat Statistik Kabupaten Majene, Sulawesi Barat.

BPS Sulawesi Barat. (2013). Sulawesi Barat Dalam Angka 2013. Badan Pusat Statistik Provinsi Sulawesi Barat. Mamuju.

CSR/FAO. (1983). Reconnaissance Land Resource Survey, 1:250.000 scale Atlas Format Prosedure. AGOF/INS/78/006 Manual 4, Version 1. Centre for Soil Research, Bogor.

Dent, F.J., Desaunettes, J.R., \& Malingreau, J.P. (1977). Detailed reconnaissance land resources surveys Cimanuk watershed area (West Java). AGL/TF/INS/44. Working Paper No.14. FAO/SRI, Bogor.

Djaenudin, D, Marwan H., Subagyo, H., Mulyani, A., \& Suharta, N. (2000). Kriteria Kesesuaian Lahan Untuk Komoditas Pertanian. Versi 3. September, 2000. Badan Litbang Pertanian. Pusat Penelitian Tanah dan Agroklimat. Dok. Puslittanak.

FAO. (1976). A Framework for Land Evaluation. Soil Resources Management and Conservation Service Land and Water Development Division. FAO Soil Bulletin No. 32. FAO-UNO, Rome.

Kips, A. Ph., Djaenudin, D., \& Suharta, N. (1981). The land unit approach to land resources surveys for land use planning with particular reference to the Sekampung watershed, Lampung Province, Sumatera., Indonesia. AGOF/INS/78/006. Technical Note No.11. Centre for Soil Research, Bogor.

Lembaga Penelitian Tanah. (1984). Petunkuk Teknis Analisis Kimia Tanah Di Laboratorium. Lembaga Penelitian Tanah, Bogor. 


\section{Macrothink}

Journal of Agricultural Studies

ISSN 2166-0379

2018, Vol. 6, No. 1

Meijerink, A. M. J. (1988). Data acquisition and data capture through terrain mapping units. ITC Journal 1988-1: 23-44.

Mitchell, C.W., \& Howard, J. A. (1978). Land System Classification. A Case History: Jordan. FAO/United Nation, Rome.

Ritung, S., Nugroho, K., Mulyani, A., \& Suryani, E. (2011). Petunjuk Teknis Evaluasi Lahan untuk Komoditas Pertanian. Balai Besar Litbang Sumberdaya Lahan Pertanian. Badan Litbang Pertanian. $161 \mathrm{Hal}$.

Soil Survey Staff. 2010. Keys to Soil Taxonomy. Eleventh Edition. United States Departement of Agriculture. Natural Resources Conservation Services.

Sudaryanto, T., \& Syafa'at, N. (1999). Perspektif sektor pertanian dan peranan kegiatan ZAE dalam pengembangan sistem usaha pertanian komoditas unggulan. Prosiding Pemberdayaan Potensi Regional Melalui Pendekatan Zone Agroekologi Menunjang Program Gema Prima (Mataram, 8-9 Maret, 1999).

Suparto \& Hartomi, D. H. (2002). Pengelolaan lahan berbasis sumberdaya lahan untuk mendukung usahatani agribisnis. Prosiding Seminar Nasional Badan Kejuruan Teknik Pertanian dan Badan Kejuruan Kimia, PII. Jakarta, Juni 2002.

van Zuidam, R. (1986). Air photo-interpretation for terrain aanalysis and geomorphologic mapping. Smits Publ. The Hague, The Netherlands.

\section{Copyright Disclaimer}

Copyright for this article is retained by the author(s), with first publication rights granted to the journal.

This is an open-access article distributed under the terms and conditions of the Creative Commons Attribution license (http://creativecommons.org/licenses/by/4.0/). 